\title{
Project Portfolio Management Strategies in Housing Estate Development Organizations in Nigeria's Built Environment
}

\author{
Sadiq Gumi Abubakar ${ }^{1}$, Jingchun Feng ${ }^{1}$, Salisu Gidado Dalibi ${ }^{1,2, *}$, Xinpeng Li $^{1}$, Chuanbin Zheng ${ }^{1}$, Liang Cao $^{1}$ \\ ${ }^{1}$ Business School, Hohai University, Nanjing City, Jiangsu Province of China. \\ ${ }^{2}$ Department of Quantity Surveying, AbubakarTafawaBalewaUniversity, Bauchi, Nigeria. \\ *salgidos@yahoo.com [corresponding Author]
}

Received March 12,2018

Accepted June 19, 2018

\begin{abstract}
Nigeria is an African country with abundant natural and human resources with an aspiration to be among the top 20 economies in world by the year 2020. Such objective can only be achieved through requisite infrastructural development projects within the Nigeria's built environment such as road, power plants and adequate housing estate development projects etc. However, Nigeria's housing estate developments were insufficient in terms of demands; do not reflect the desired housing needs of the end-users; in some-cases affordable but not qualitative; do not possess green building features. These has led to challenges and questions about project portfolio management (PPM) strategies that align and fit portfolios with the organizational objectives while also delivering estate development projects that are less risky and marketable. The aim of this research paper is to assess the PPM strategies used by housing estate development organizations in Nigeria's built environment with a view of identifying, examining, and highlighting the impact of these strategies on housing estate development project portfolios in Nigeria. Literature reviewed led to identification and assessment of five PPM strategies. Krejcie and Morgan table was used to determine the sample size, while Cronbach's alpha, mean item scores, relative importance index, T-test statistics were used for data analyses. The results show that any chosen PPM strategy(ies) by Housing Estate Development organizations will not be easy to apply, use, implement nor will it be excellent in the strive to achieve the Organizational Objectives in any given Portfolio.
\end{abstract}

Key words: Built environment, Factors, Housing Estates, Nigeria, Organizations, Portfolio, Projects, Strategies

\section{Introduction}

\subsection{Background to the Study}

Nigeria is often referred to as the "Giant of Africa", owing to its large population and Economy. With its abundant natural and human resources, it also harbors a long term aspiration to be among the top 20 economies in the world by the year 2020. (Holmes, 1987; CIA, 2014; wikipedia.org/wiki/Nigeria; Library of Congress, 2008; Bloomberg.com 2014 and ADB, 2013). These lofty objectives can only be realized through the requisite infrastructural development projects such as roads and rail networks, bridges, power generation projects and adequate housing estate development projects etc., within Nigeria's built environment. These will make the built environment economically and investment viable in addition to the aforementioned resources. According to Olatunji et al. (2016), the construction industry is vital for the development of any nation. In many ways, the pace of the economic growth of any nation can be measured by the development of physical infrastructures, such as buildings, roads and bridges etc. The PMI (2017), stated that Projects enable business value creation. These Business value in projects refers to the benefit that the results of a specific project provide to its stakeholders that may be tangible, intangible, or both (PMI, 2017).

Moreover, Projects are known to be the engine and catalyst for developments while adequate financing and funding are simply the fuel that makes the engine (projects) work. The Public organizations (Government), the Private Organizations (Investors) or a partnership of both known generally as the clients normally initiate such projects. In some cases, many projects will be ongoing simultaneously and each has its own budget and duration while some may be similar, others are entirely different; all are meant to serve a business and or some specific organization's objectives. A collection of projects is called a program and largely a portfolio (Sadiq et al., 2018).

While a project is a temporary endeavor undertaken to create a unique product, service, or result; a program is defined as a group of related projects, subsidiary 
programs, and program activities managed in a coordinated manner to obtain benefits not available from managing them individually; whereas a portfolio is defined as projects, programs, subsidiary portfolios, and operations managed as a group to achieve strategic objectives. Some organizations may employ the use of a project portfolio to effectively manage multiple programs and projects that are underway at any given time.

Portfolio Management (PfM) can be referred to as: Combination of projects under the sponsorship of a particular organization sharing scarce resources (Archer and Ghasemzadeh,1999; Jonas et al., 2012); a set of business practices that integrates projects with other business operations (Levine, 2005; Archer and Ghasemzadeh, 2004; Dammer and Gemunden, 2006); a dynamic decision making process whereby new projects are evaluated, selected, and prioritized; existing projects are accelerated, terminated, or de-prioritized; and resources are allocated and re-allocated to the active projects (Cooper et al., 2000); Involves projects that are selected and managed in line with strategy and that resources are allocated to projects with the optimization of the entire portfolio in mind (Archer and Ghasemzadeh,1999a and b; Artto and Dietrich, 2004; Artto et al., 2004). As such, various organizations adopt different approaches and strategies when managing projects and programs within a portfolio. These may be linked to how the organizations' portfolio of projects are evaluated, selected, and prioritized etc. Housing Estate development organizations in Nigeria are no exceptions.

\subsection{The Research Problem}

It appears that the attention project portfolio managers give to portfolio activities is inadequate and working with multiple projects overloads the employees (Zika-Viktorsson et al., 2006; Elonen and Artto, 2003). The alignment between project portfolios and customer relationship portfolios is a missing link which is implicitly reflected in the objectives of single projects because their results should satisfy a certain hierarchy of their needs and satisfaction (Voss, 2012). PPM can be understood as the hub of an intra-company system that connects projects and operations (Floricel and Ibanescu, 2008). These requires different decision situations and different decision making approaches, which some authors asserted that combining decision-making approaches that were based on different logics might be difficult (Floricel and Ibanescu, 2008) and it might lead to conflicts within the organization (Bessant et al., 2011). In addition, the dilemma in resource sharing is poorly understood and hardly solved in project portfolios and is just one among others. Many other deviations from the companies' PPM frameworks appear in the day-to-day practice (Blichfeldt and Eskerod, 2008). Despite the variety of instructions on how projects should be selected to the portfolio, how resources should be allocated across projects, how to align the entire portfolio with strategy, and how to assess the success of the portfolio, companies still struggle with the resource sharing problem across projects (Engwall and Jerbrant, 2003) as well as constant changes in their portfolios (Elonen and Artto, 2003). These may be linked to the organizational choice of PPM strategies.

In Nigeria's built environment, housing estate development organizations developed and delivered many housing estates alone or through partnerships with the private sector. However, such housing estate developments were insufficient in terms of demands; do not reflect the desired housing needs of the end-users; in some-cases affordable but not qualitative; do not possess green building features (Dalibi et al., 2016). As such, housing estate development organizations are faced with challenges of project portfolio management (PPM) strategies that align and fit with their organizational objectives while also delivering estate development projects that are less risky and marketable. These will require a lot of expertise and effective strategies from the portfolio managers in the housing estate development organizations which is a huge challenge.

\subsection{Research Aim and Scope}

The aim of this research paper is to assess the PPM strategies used by housing estate development organizations in Nigeria's built environment with a view of identifying, examining, and highlighting the impact of these strategies on housing estate development project portfolios in Nigeria. The study only focuses on the housing estate development project portfolios. It does not include stocks portfolios in the aforementioned organizations.

\subsection{Research Hypothesis}

To address the research problem and fully achieve the research aim, the following Hypotheses were formulated and tested using the appropriate statistical tool:

Null Hypothesis - $\boldsymbol{H}_{\boldsymbol{O}}$ : Project Portfolio Management Strategies used by Housing Estate Development organizations within the built environment in Nigeria are not significantly effective.

Alternative Hypothesis - $\boldsymbol{H}_{A}$ : Project Portfolio Management Strategies used by Housing Estate Development organizations within the built environment in Nigeria $\underline{\text { are }}$ significantly effective.

\section{Literature Review}

\subsection{Project Portfolio Management (PPM) and the Executing Organizations}

A portfolio is a collection of projects or programs and other work that are grouped together to facilitate effective management of that work to meet strategic business objectives. An organization may have more than one portfolio, each addressing unique business areas or objectives. Proposed initiatives become part of the portfolio when they are identified, selected, and/or approved. (PMI, 2008a and b)

At any given moment, the portfolio represents a view of its selected components and reflects the strategic 
goals of the organization; however, specific projects or programs within the portfolio are not necessarily interdependent or directly related. By reflecting investments made or planned by an organization, portfolio management includes the processes for identifying the organizational priorities, making investment decisions, and allocating resources. Therefore, the portfolio represents the work selected to be done, but not necessarily the work that should be done. If a portfolio's components are not aligned to its organizational strategy, the organization can reasonably question why the work is being undertaken. Therefore, a portfolio is a true measure of an organization's intent, direction and progress. Portfolio management is an opportunity for a governing body to make decisions that control or influence the direction of a group of components (a sub-portfolio, program, projects, or other work) as they work to achieve specific outcomes. An organization uses the tools and techniques described in this standard to identify, select, prioritize, govern, monitor, and report the contributions of the components to, and their relative alignment with, organizational objectives. It is not concerned with managing the components. The goal of portfolio management is to ensure that the organization is "doing the right work," rather than "doing work right." (Ibid)

Most Projects landscapes are becoming more complex. In addition to effective and efficient single project management, companies require structured and proactive management of the project landscape to stay competitive (Elonen and Artto, 2003). PPM integrates projects with other business operations and that includes key activities such as decision making on which projects are to be given priority, which projects are to be added to or abandoned /taken out of the portfolio, and how to allocate resources (Archer and Ghasemzadeh, 2004; Dammer and Gemünden, 2006). Among the key issues has been that projects are selected and managed in line with strategy and that resources are allocated to projects with the optimization of the entire portfolio in mind (Archer and Ghasemzadeh, 1999a, b; Artto and Dietrich, 2004; Artto et al., 2004; Englund and Graham, 1999). Centering resources for a single project can also benefit the entire portfolio as project execution speed may be maximized and new products can be brought to market rapidly. Most of these start with the single projects which is an integral part of a portfolio of an organization (Martinsuo and Lehtonen, 2009).

As the number of projects increases, it is particularly important to guarantee effective and efficient execution of project portfolios. This remains a challenge despite the formalization of single projects, which facilitates faster process implementation and better process quality (Ahlemann et al., 2009; Garcia, 2005). In parallel, companies are confronted with customers demanding value-adding activities, such as joint product development, financing, or consulting services (Homburg et al., 2002). Companies introduce concepts and processes such as customer relationship management
(CRM) or key account management for a closer customer relationship and better service, aiming to create value both for the customer and for the company (Ernst et al., 2011; Frow and Payne, 2009; Boulding et al., 2005). Furthermore, customer prioritization and the management of customer portfolios have received more attention in research and practice (Homburg et al., 2008; Homburg et al., 2009; Terho, 2009). A customer portfolio should be managed along the customers' valuable contributions to the relationship portfolio, not just the customers' valuable contributions to the firm alone (Homburg et al., 2009). However, optimization of individual portfolios does not necessarily optimize the overall business performance; an alignment between the different portfolios is needed (Tikkanen et al., 2007). This is where PPM strategies come into play as they provide the requisite direction on how best to align organizational objectives within the portfolios and achieve a favorable outcome for the organization.

Project portfolio management (PPM) must deal with the coordination and control of multiple projects. As such the Project portfolio managers pursue the same strategic goals and compete for the same resources, whereby managers prioritize among projects to achieve strategic benefits (Cooper et al., 1997a). Companies have adopted project portfolio management frameworks, including the use of project evaluation and decision criteria, project evaluation and control routines, and other means to formalize their project portfolio management (PMI, 2008; Benko and McFarlan, 2003; Cooper et al., 2001; Martinsuo and Poskela, 2011; Muller et al., 2008; Teller et al., 2012).

The rational approach appears to assume that projects are obedient servants that exist primarily to fulfill the strategy of the parent organization.However, innovation projects are frequently used to purposefully question the strategy and are no longer necessarily limited to one company's strategic interests only (Artto et al., 2008a, b). Also, there is a rational approach which appears to assume that companies are fully aware of all possible factors both internal and external - influencing the projects. Many of the previous studies delimit their attention to the projects that are well defined and whose environments are well known, even if also less welldefined projects are being found in portfolios and many portfolio environments are inherently poorly known (Blichfeldtand Eskerod, 2008; Loch, 2000).

\subsection{Project Portfolio Management (PPM)Strategies}

PPM execution contexts can somehow be embedded into criteria and routines that align the projects with strategy and, eventually, bring strategic benefits. Yet, there is increasing evidence that portfolio managers are not necessarily well informed (Blichfeldt and Eskerod, 2008; Elonen and Artto,2003) and the criteria and routines do not solve multi-project problems as expected (Engwall and Jerbrant, 2003; Zika-Viktorsson et al., 2006). 
Project Portfolio Managers in Housing estate development organizations also faced with dynamic challenges in evaluation and decision criteria, project evaluation and control routines, and other means to formalize their project portfolio management especially the strategy to adopt in the estate development portfolios. The decision to go with quantitative or qualitative housing scheme depends on a wide range of factors such as internal (within the organization) and external (beyond the organizational control) which may include but not limited to housing demand, end-users' income / buying / purchasing power, the location, stakeholders, sociopolitical stability, availability of funds and resources etc.

Incorporating some features / elements especially green building elements are basically at the estate developer's disposal in Nigeria's estate development projects and these may have a significant impact on the total development cost which in turn affects end-users / occupants in terms of Rental value, Sales value, Envisaged savings due to such elements, Future asset value of the development etc. Thus, those elements if not checked with potential end-users in order to ensure they meet their housing needs, requirements and also their affordability which will also reflect on the developers' interests in terms of market value and faster sale of the Housing units. These all together outlined the need for housing estate development projects with features that can align the interests of the stakeholders in such development projects (Dalibi et al., 2016). As such, these must be taken into the PPM strategy of housing estate developments to ensure profitability which also ensures the viability of the portfolio.

Managing Portfolios requires an effective strategy that will ensure success, reduce risk and achievement of the organizational objectives. Portfolio Management Strategies refer to the approaches that are applied for the efficient portfolio management in order to generate the highest possible returns at lowest possible risks. There are two basic approaches for portfolio management including Active Portfolio Management Strategy and Passive Portfolio Management Strategy Others include Patient Portfolio Management Strategy, Conservative Portfolio Management Strategy and Patient Portfolio Management Strategy (Sushant, 2018).

\subsubsection{Active PPM Strategy}

Active Portfolio Management Strategy refers to a portfolio management strategy that involves making precise investments for outperforming an investment benchmark index. The risk reduction is considered a goal of creating an investment return larger than the benchmark by considering and using large number of factors and strategies for constructing the portfolio (Sushant, 2018). Active portfolio management means allocation of funds based on expectations of future market developments; it is also the implementation of a dynamic investment strategy that over- and under weights the predefined investment opportunities over a long-term basis, with the single objective of outperforming the predefined benchmark at a predefined time in order to add value to the portfolio. (Hilsted, 2012). The success of an actively-managed portfolio is dependent on combining in-depth research, market forecasting and the experience and expertise of the portfolio manager or management team. The portfolio managers that engaged in active strategy pay close attention to market trends, shifts in the economy, changes to the political landscape and factors that may affect specific companies. It involves all efforts to take advantage of irregularities. Active managers claim that these processes will boost the potential for greater returns than those listed on a particular index. (Investopedia). Active PPM with respect to housing estate development organizations involves:

Top-down Approach: In this approach, managers observe the market as a whole and decide where and what type of estate development projects will perform well in the ongoing economic cycle.

Bottom-up: In this approach, the housing estate market conditions and its expected trends are ignored and the evaluations of the PPM organizations were based on their respective strengths and capabilities, which if positioned well will allow the organizations perform better irrespective of the prevailing market or economic conditions.

The success, performances and effectiveness of an actively managed portfolio is directly dependent on the skills, expertise and research abilities of the PPM team, while also engaging the stakeholders inside and outside the organization.

\subsubsection{Passive PPM Strategy}

Passive portfolio management relies on the fact that markets are efficient and it is not possible to beat the market returns regularly over time and best returns are obtained from the low cost investments kept for the long term (Sushant, 2018). This strategy, also involves portfolio rebalancing. This implies that there is much emphasis on asset classes with weights comparable to a benchmark contribute with the largest proportion of the total return of the portfolio (Hilsted, 2012). Passive PPM Focuses on overall sector or asset class is based on the concept of the efficient market, which states that because all investors have access to all the necessary information it's difficult if not impossible to gain an advantage over any other investor. As new information becomes available, market prices adjust in response to reflect a security's true value. The proponents of market efficiency say "it means that reducing investment costs is the key to improving net returns". (Raymond Jones \& Associates). As such, housing estate development organizations need them to acquire, disseminate and interpret all the necessary information in this regard and make decisions that fit the organizational objectives within their respective project portfolios. These will also require a lot of expert judgments within the PPM team. 


\subsubsection{Patient PPM Strategy}

Patient PPM strategy involves making investments in well-known type of projects / programs / operations etc. It involves and represent companies that have classic growth and those expected to generate higher earnings on a regular basis irrespective of financial conditions (Sushant, 2018). The knowledge about which projects / programs / operations will perform enables PPM team of various organizations to be in a "Patient Mode" and take longer periods before making the appropriate decisions on projects / programs / operations within portfolios or the entire portfolio to invest, reinvest or divest.

\subsubsection{Aggressive PPM Strategy}

Aggressive PPM strategy involves making expensive investments that provide good returns and big rewards long with carrying big risks (Sushant, 2018). Housing estate development organizations employ such strategy for projects that are located in areas that have high prospects for physical, economic and social development bearing in mind that the target population are high earners and big spenders.

lower risk securities and equities

(www.investopedia.com). This is done after carefully observing the market returns, earnings growth and consistent dividend history (Sushant, 2018). Such PPM strategies usually seek to provide both capital appreciation and income to the investing organization. A conservative portfolio is appropriate for an investor with a low risk tolerance and a time horizon from immediate to longer than 3 years. (www.thebalance.com). Conservative PPM investors do not have to grapple with the increasing volatility in the markets and is suitable where Rates have remained low and demand has been high. (www.forbes.com). Table 1 summarizes the PPM strategies with a brief description respectively.

Irrespective of the PPM strategy used by organizations, expert judgment (from professionals with decades of experience) is vital and is used by the portfolio management team to assess the inputs needed to compare the components and to apply it to any technical and management details during this process. The portfolio management team also applies expert judgment to identify relationships between components, which are

Table 1: Portfolio Management Strategies and their brief description

\begin{tabular}{|c|c|c|}
\hline $\mathbf{S} / \mathbf{N}$ & Project Portfolio Management Strategy & Description \\
\hline 1 & Active Portfolio Management Strategy & $\begin{array}{l}\text { Divided into Top-down Approach and Bottom-up Approach; } \\
\text { It is based on expectations of future market developments with the single } \\
\text { objective of outperforming the predefined benchmark at a predefined time in } \\
\text { order to add value to the portfolio. }\end{array}$ \\
\hline 2 & Passive Portfolio Management Strategy & $\begin{array}{l}\text { Management and financial investment strategy that requires Efficient market } \\
\text { information handling in an Organization. All investors have access to all the } \\
\text { necessary information that makes it difficult if not impossible to gain an } \\
\text { advantage over any other investor. }\end{array}$ \\
\hline 3 & Patient Portfolio Management Strategy & $\begin{array}{l}\text { Decision-based on the well-knowntype of projects/programs / operations } \\
\text { expected to generate higher earnings on a regular basis irrespective of financial } \\
\text { conditions }\end{array}$ \\
\hline 4 & Aggressive Portfolio Management Strategy & $\begin{array}{l}\text { Decision-based on expensive markets with favorable returns along with } \\
\text { carrying big risks. }\end{array}$ \\
\hline 5 & Conservative Portfolio & $\begin{array}{l}\text { Carefully observing the market returns, earnings growth and consistent } \\
\text { dividend history }\end{array}$ \\
\hline
\end{tabular}

This will allow the portfolio(s) to generate rapid and faster returns on the projects portfolio investments. Such strategy also requires expert judgements and the use of investment appraisal methods or techniques. Atrill \& McLaney (2011) outlined four main methods of investment appraisal as: Accounting Rate of Return (ARR); Payback Period (PP); Net Present Value (NPV) and Internal Rate of Return (IRR). The interpretation, application and decision on any of the methods will be based on the skills and expertise of the PPM team.

\subsubsection{Conservative PPM Strategy}

Conservative PPM is an investing strategy that seeks to preserve an investment portfolio's value by investing in under consideration. Such relationships may be independent components or components coupled which include: Dependencies, Redundancies, Partial overlap, and Mutual exclusivity of components. (PMI, 2008).

\section{Research Methodology}

The main sources of data were from journals, conference/seminar/workshop papers, textbooks, newspapers, magazines and the internet etc. which were used to review literature in the Project Portfolio Management (PPM), Organizations, Business, Housing Estate and its operations related areas which helps to identify and narrow PPM strategies within the Nigerian and Global Context. These identified PPM strategies 
form the backbone of the Questionnaire, which was distributed to various Professionals in PPM housing estate development organizations in Nigeria. The research design encompasses the following:

Krejcie and Morgan(1970) table of determining sample size for any given population to determine the research sample size which fixes 384 as the sample size of a maximum number for a given population of 1,000 , 000. As such, up to 740 number of questionnaires were distributed to enable the retrieval of the required sample number.

A 5-point Likert scale was used in obtaining and analyzing the perceptions of various professionals working in the organizations' PPM teams. Mean Item Score was calculated using the formula:

$$
\frac{5\left(X_{5}\right)+4\left(X_{4}\right)+3\left(X_{3}\right)+2\left(X_{2}\right)+1\left(X_{1}\right)}{N}
$$

The values of the mean item scores were used to pass remarks for the strategies analyzed. Excellent / Extremely Difficult for all values between 4.5 to 5; Very Good / Very Difficult for all values between 3.5 to 4.4; Good / Difficult 2.5 to 3.4; Satisfactory / Not Difficult for all values between 1.5 to 2.4 and Poor / Not at all for all values between $0.5-1.4$.

Relative Importance Indices (RII) were used to rank the perceptions. The RII for a 5-point Likert scale were calculated using the formula below.

$$
\frac{5\left(X_{5}\right)+4\left(X_{4}\right)+3\left(X_{3}\right)+2\left(X_{2}\right)+1\left(X_{1}\right)}{5 \times N}
$$

The values for the RII allows for ranking of the PPM strategies in terms of performances, ease of use implementation/applications.

Cronbach's Alpha was used to measure the reliability of the responses from the 5-point Likert scale. In this part, all the questions structured using the 5-point Likert scale were subjected to reliability test using the Cronbach's alpha. Reliability pertains to the consistency of scores. The less consistency within a given measurement, the less useful the data may be in analysis. Cronbach's alpha provides a useful lower bound on reliability which will generally increase when the correlations between the items increase. As such, the coefficient measures the internal consistency of the test. Its maximum value is 1 , and the minimum is 0 , although it can be negative. Tavakol and Dennick (2011), concluded that Cronbach's Alpha is an important concept in the evaluation of assessments and questionnaires. It is mandatory that assessors and researchers should estimate this quantity to add validity and accuracy to the interpretation of their data. Table 2 below shows the corresponding interpretation of the values for Cronbach's alpha.

Cronbach's alpha computation was carried out using the formula below:

Alpha $=N /(\mathrm{N}-1) \times($ Total Variance - Sum of Variance for Each Question) / Total Variance.

Table 2: Cronbach's Alpha Numerical Value Remark
\begin{tabular}{|c|c|}
\hline CRONBACH'S ALPHA & $\begin{array}{c}\text { INTERNAL } \\
\text { CONSISTENCY }\end{array}$ \\
\hline Alpha $\geq 0.9$ & Excellent \\
\hline $0.9>$ Alpha $\geq 0.8$ & Good \\
\hline $0.8>$ Alpha $\geq 0.7$ & Acceptable \\
\hline $0.7>$ Alpha $\geq 0.6$ & Questionable \\
\hline $0.6>$ Alpha $\geq 0.5$ & Poor \\
\hline $0.5>$ Alpha & Unacceptable \\
\hline
\end{tabular}

where $N=K$, is the number of items; Summation of delta-squared-k is the sum of the $\mathrm{k}$ item score variances, and the delta-squared total is the variance of scores on the total measurement.

A t-test was used to test the research Hypothesis. The formula is shown below.

$$
\text { Ttest }=\frac{X b a r-\mu_{0}}{s \sqrt{n}}
$$

where X-Bar- is the mean of a random sample from a given population, $\mu_{\mathrm{o}}$ is the mean specified in the null hypothesis, Delta is the standard deviation of a random sample from the population, and $n$ is the size of the sample used to compute and the mean and standard deviation.

Microsoft Excel and Statistics resource pack were used for the overall analyses.

\section{Data Presentation and Analyses}

\subsection{Research Response Rate}

The responses from the research questionnaires that were distributed electronically and manually were shown in table 3 below, which clearly shows that 740 number of questionnaires were distributed, out of which 351 number (47\%) were not returned; while 389 number (53\%) were returned. Among the responsive 389 number of questionnaires, 211 number $(54.1 \%)$ were responses from the electronically distributed questionnaires (EQuestionnaires) while 178 number (45.9\%) were responses from the manually distributed questionnaires. As such, the response from E-Questionnaires was higher in this study.

\subsection{Research Reliability Test using Cronbach's Alpha}

A total of ten questions were asked in a table format (shown in the appendix) and analyzed. Using the formula for the Cronbach's alpha in table 2 above, the reliability scores and remarks for the 5-point Likert scale responses were shown in Table 4 below. 
Table 3: Electronically and manually distributed Questionnaire Responses

\begin{tabular}{|c|c|c|c|c|}
\hline Questionnaires & Distributed & Returned & $\begin{array}{c}\text { Non- } \\
\text { Returned }\end{array}$ & Percentage \\
\hline Manually distributed & 340 & 178 & 162 & $45.9 \%$ \\
\hline TOTAL & 740 & 389 & 351 & $100 \%$ \\
\hline
\end{tabular}

Table 4: Alpha's Reliability Test and Remarks

\begin{tabular}{|c|c|c|c|c|c|c|c|}
\hline $\begin{array}{c}\text { QUESTIONS \& THEIR } \\
\text { SCALE } \\
\text { COMPONENTS }\end{array}$ & $\mathbf{N}$ & N-1 & $\begin{array}{c}\text { VARIANCE } \\
\text { (V) }\end{array}$ & $\begin{array}{c}\text { TOTAL } \\
\text { VARIANCE }(\mathrm{TV})\end{array}$ & TV $-\mathbf{V}$ & $\begin{array}{c}\text { CRONBACH'S } \\
\text { ALPHA }\end{array}$ & $\begin{array}{c}\text { SCORE } \\
\text { REMARK }\end{array}$ \\
\hline 5-Points & 10 & 9 & 3740.20 & 21744.70 & 18004.50 & 0.92 & Excellent \\
\hline 4-Points & 10 & 9 & 5159.89 & 21744.70 & 16584.81 & 0.85 & Good \\
\hline 3-Points & 10 & 9 & 1015.56 & 21744.70 & 20729.14 & 1.06 & Excellent \\
\hline 2-Points & 10 & 9 & 6194.64 & 21744.70 & 15550.06 & 0.79 & Acceptable \\
\hline 1-Points & 10 & 9 & 5634.41 & 21744.70 & 16110.29 & 0.82 & Good \\
\hline & & & & AVERAGE & $=$ & 0.89 & Good \\
\hline
\end{tabular}

These clearly indicate that there is a good consistency of scores from the Likert scale by the various respondents with both the 5-points and 3-points scales having Excellent remarks; 4-points and 1-point scales having Good remarks while 2-points scale has the least with an acceptable remark which may be some-what Good (if approximated). As such the average / overall reliability of the 5-points scale structure for the responses analyzed in this study regarding PPM strategies is 0.89 which is good and may be some-what Excellent (if approximated).

\subsection{Ease of Application, Use andImplementation of PPM strategies}

This part shows the perceptions of various PPM professions regarding the ease of implementation/ application for the aforementioned five PPM strategies. These were structured using a five-point Likert scale as shown in the table 5 below.
From the table above, it can be deduced regarding Organizational Project Portfolio Management (PPM) Strategies \& Ease of Application within Organizations that the Active Portfolio Management Strategy and Passive Portfolio Management Strategy are the strategies that are very difficult to apply, use and implement by organizations. Whereas; Patient Portfolio Management Strategy; Aggressive Portfolio Management Strategy; Conservative Portfolio are strategies that are not difficult to apply, use and implement by organizations. Active Portfolio Management Strategy ranked $1^{\text {st }}$; this is followed by Passive Portfolio Management Strategy which is also very difficult and ranked $2^{\text {nd }}$. Whereas; Patient Portfolio Management Strategy ranked $3^{\text {rd }}$; Aggressive Portfolio Management Strategy ranked $4^{\text {th }}$; Conservative Portfolio ranked $5^{\text {th }}$ as the least strategy in terms difficulties to apply, use and implement by organizations. 
4.4 Performances of Project Portfolio Management (PPM) Strategies for Achieving Organizational Objectives in Portfolios
This part covers the performance of PPM strategies within Organizations. The data and the analyses were shown in table 6 below.

Table 5: Project Portfolio Management (PPM) Strategies \& Ease of Application within Organizations

\begin{tabular}{|c|c|c|c|c|c|c|c|c|c|c|c|}
\hline $\mathbf{S} / \mathbf{N}$ & $\begin{array}{l}\text { Project Portfolio Management } \\
\text { Strategies \& Ease of Application }\end{array}$ & 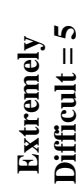 & & 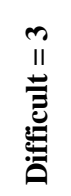 & 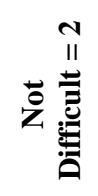 & $\begin{array}{l}\overline{\text { II }} \\
\frac{\bar{\sigma}}{\tilde{\sigma}} \\
\stackrel{\overrightarrow{0}}{z}\end{array}$ & 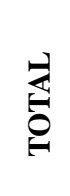 & 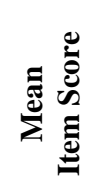 & 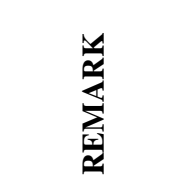 & 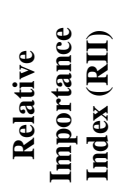 & 弟 \\
\hline 1 & Active Portfolio Management Strategy & 181 & 149 & 45 & 11 & 3 & 389 & 4.27 & $\begin{array}{c}\text { Very } \\
\text { Difficult }\end{array}$ & 0.85 & 1 st \\
\hline 2 & Passive Portfolio Management Strategy & 171 & 44 & 103 & 61 & 10 & 389 & 3.78 & $\begin{array}{c}\text { Very } \\
\text { Difficult }\end{array}$ & 0.76 & 2nd \\
\hline 3 & Patient Portfolio Management Strategy & 32 & 29 & 68 & 187 & 73 & 389 & 2.38 & Not Difficult & 0.48 & $3 \mathrm{rd}$ \\
\hline 4 & Aggressive Portfolio Management Strategy & 10 & 13 & 109 & 228 & 29 & 389 & 2.35 & Not Difficult & 0.47 & 4th \\
\hline 5 & $\begin{array}{lll}\begin{array}{l}\text { Conservative } \\
\text { Strategy }\end{array} & \text { Portfolio } & \text { Management } \\
\end{array}$ & 19 & 27 & 56 & 219 & 68 & 389 & 2.25 & Not Difficult & 0.45 & 5 th \\
\hline
\end{tabular}

Table 6: Performances of Project Portfolio Management Strategy in Achieving Organizational Objectives in Portfolios

\begin{tabular}{|c|c|c|c|c|c|c|c|c|c|c|c|}
\hline $\mathbf{S} / \mathbf{N}$ & $\begin{array}{l}\text { Performances of Project Portfolio } \\
\text { Management Strategies in Achieving } \\
\text { Organizational Objectives in Portfolios }\end{array}$ & In & 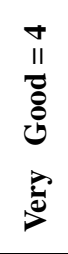 & mo & 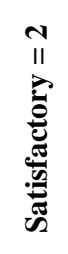 & $\stackrel{\vec{I}}{I I}$ & 育 & 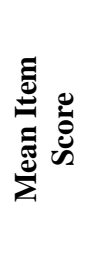 & 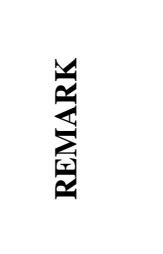 & 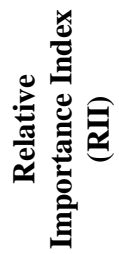 & 䜦 \\
\hline 1 & Active Portfolio Management Strategy & 57 & 147 & 85 & 88 & 12 & 389 & 3.38 & Good & 0.68 & $3 \mathrm{rd}$ \\
\hline 2 & Passive Portfolio Management Strategy & 71 & 44 & 121 & 133 & 20 & 389 & 3.03 & Good & 0.61 & 4 th \\
\hline 3 & Patient Portfolio Management Strategy & 88 & 189 & 68 & 28 & 16 & 389 & 3.78 & Very Good & 0.76 & 2 nd \\
\hline 4 & Aggressive Portfolio Management Strategy & 15 & 11 & 19 & 79 & 265 & 389 & 1.54 & Satisfactory & 0.31 & 5 th \\
\hline 5 & Conservative Portfolio Management Strategy & 136 & 196 & 34 & 12 & 11 & 389 & 4.12 & Very Good & 0.82 & $1 \mathrm{st}$ \\
\hline
\end{tabular}

From the table above, it can be deduced regarding Performances of Project Portfolio Management (PPM) Strategies in Achieving Organizational Objectives in Portfolios that the Conservative Portfolio management strategy and Patient Portfolio Management Strategy are the PPM strategies with Very Good performances in organizations. While Passive Portfolio Management Strategy and Active Portfolio Management Strategy have Good performance. The Aggressive Portfolio Management Strategy is the strategy with the Satisfactory performanceamong the Project Portfolio Management (PPM) strategies in achieving Organizational Objectives within Portfolios.
The Conservative Portfolio ranked $1^{\text {st }}$; this is followed by Patient Portfolio Management Strategy which ranked $2^{\text {nd }}$; Passive Portfolio Management Strategy ranked $3^{\text {rd }}$; Active Portfolio Management Strategy ranked $4^{\text {th }}$ and the Aggressive Portfolio Management Strategy is the least ranked as $5^{\text {th }}$ in terms of performancesamong the PPM strategies in Achieving Organizational Objectives in Portfolios.

\subsection{Testing the Research Hypothesis}

The values of the mean item scores for all the questions structured using the Likert scales (in table 5 and 6) were used to calculate the T-test statistics and the result is shown in table 7 below. 
Table 7: Result for Hypotheses test using T-test statistics

\begin{tabular}{|c|c|c|c|c|c|c|c|c|c|c|}
\hline PPM Strategies & 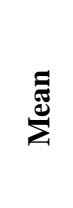 & 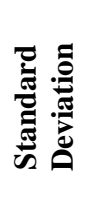 & 总 & $\mathbf{Z}$ & 原 & 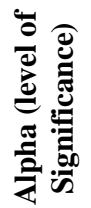 & 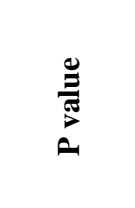 & $\begin{array}{l}\text { కే } \\
\text { F }\end{array}$ & 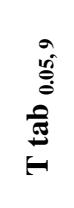 & 芯 \\
\hline $\begin{array}{c}\text { PPM Strategies Ease of Application and } \\
\text { Performance }\end{array}$ & 3.09 & 0.92 & 0.29 & 10 & 9 & $5 \%$ & $3.73 \mathrm{E}-02$ & 10.59 & 1.83 & Yes \\
\hline
\end{tabular}

With 9 degrees of freedom (DF) and 5\% level of significance, the T-test calculated (Tcal $=10.59)$ is greater than $\mathrm{T}$-test tabulated $\left(\mathrm{T}-\mathrm{tab}_{0.05,9}=1.83\right)$; the significance level (alpha $=0.05$ ) is greater than the Probable value $(\mathrm{P}$-value $=0.037)$. As such, the null hypothesis was rejected and the alternative hypothesis was accepted. These clearly indicate that the Project Portfolio Management Strategies used by Housing Estate Development organizations within the built environment in Nigeria are significantly effective. This is evident from the analyses in table 5 and 6 above which shows that four out of five of the strategies perform above the satisfactory level which indicates their effectiveness (as indicated and affirmed by the hypothesis tested above).

\section{Discussions, Conclusions \& Recommendations}

The analyses above paved the way for the following discussions and conclusions:

Any chosen PPM strategy(ies) by Housing Estate Development organizations will not be easy to apply, use and implement. As such, it will require expertise, experience, management and tracking skills from the PPM team to achieve. The performances of any chosen PPM strategy(ies) by Housing Estate Development organization will not be excellent in achieving Organizational Objectives in Portfolios. As such, the performance of any chosen strategy(ies) by the PPM organization can only be very good, good or satisfactory in the strive to achieve the Organizational Objectives in any given Portfolio. These may be related to factors outside the organizational control such as the dynamic market environment.

Project Portfolio Management Strategies used by Housing Estate Development organizations within the built environment in Nigeria aresignificantly effective as attested by the Research Hypotheses. This may be related to the assessment of the performances of the PPM strategies used in managing project portfolios in the organizations where Conservative and Patient Portfolio Management Strategy were deemed Very Good in terms of performances while Passive and Active Portfolio Management Strategy have Good performance. The Aggressive Portfolio Management Strategy is the strategy with the Satisfactory performanceamong the Project Portfolio Management (PPM) strategy in Achieving Organizational Objectives in Portfolios. These clearly indicate that most Housing Estate Development organizations are not willing to adopt and or be active in this regard which may be due to investment risks within Nigeria's built environment and the market or economic related factors.

Irrespective of the PPM strategy used by organizations, expert judgment (from professionals with decades of experience) is vital and is used by the portfolio management team to ensure that any chosen PPM strategy is workable in the pursuit of organizational objectives in portfolios. assess the inputs needed to compare the components and to apply it to any technical and management details during this process.

This study reviewed, identified, assessed and examine five PPM strategies in Housing Estate Development organizations in Nigeria's built environment within a scope and some limitations. As such the following recommendations were proffered for further research:

An Examination of the factors hindering implementation of any PPM strategy(ies) in Nigeria's built environment.

An investigation of the relationship between the dynamic business environment and the performances of PPM strategies.

Empirical research to examine the factors shaping PPM strategies in Nigeria's built environment.

A research to determine the Stakeholder's roles and performances in achieving PPM strategies in Nigeria's built environment.

\section{References}

Peter Holmes, (1987). Nigeria: Giant of Africa. The Oregon Press.

The CIA World Fact Book (2014). Sky horse Publishing, Inc. 2013. ISBN 978-1-62636-073-0.

URL: https://en.wikipedia.org/wiki/Nigeria.

Library of Congress - Federal Research Division (July 2008). "Country profile: Nigeria".

Nigeria becomes Africa's largest economy. Available at: URL:https://www.bloomberg.com/news/2014-0406/nigerian-economy-overtakes-south-africa-s-onrebased-gdp.html. Accessed December, 2017.

African Development Bank Group (2013). Federal Republic of Nigeria Country Strategy Paper, 20132017.

Samuel Olusola, Olatunji, Ayodeji Emmanuel, Oke, Douglas Omoregie, Aghimien, Seidu, Sakiru Adeyemi (2016). "Effect of Construction Project 
Performance on Economic Development of Nigeria," Journal of Economics and Sustainable Development, vol. 7, no. 12, pp. ISSN 2222-1700 (Paper) ISSN 2222-2855 (Online) , 2016.

Project Management Institute - PMI, (2017). A Guide to the Project Management Body of Knowledge (PMBOK ${ }^{\circledR}$ Guide) 6th Edition. published by PMI, Newton Square, P.A.

Sadiq Gumi Abubakar, Salisu Gidado Dalibi and Yuting Wang (2017). Factors Shaping Project Portfolio Management in Nigeria's Built Environment. International Journal of Economics, Commerce \& Management, UK. Vol VI. Issue 3.

Archer, N., Ghasemzadeh, F., (1999a). An integrated framework for project portfolio selection. Int. J. Proj. Manag. 17 (4), 207-216.

Jonas, D., Kock, A., Gemünden, H.G., (2012). Predicting project portfolio success by measuring management quality - a longitudinal study. IEEE Transactions on Engineering Management PP (99), 1-12. http://dx.doi.org/ 10.1109/TEM.2012.2200041.

Levine, H.A., (2005). Project Portfolio Management-A Practical Guide to Selecting Projects, Managing Portfolios, and Maximizing Benefits. Jossey-Bass, San Francisco, CA.

Archer, N.P., Ghasemzadeh, F., (2004). Project portfolio selection and management. In: Morris, P.W.G., Pinto, J.K. (Eds.), The Wiley Guide to Managing Projects. John Wiley \& Sons, New York, NY.

Dammer, H., Gemünden, H.G., (2006). MultiProjektManagement-Kritische Erfolgsfaktoren zum Management von Projektelandschaften. Technische Universität Berlin, Berlin, Germany.

Cooper, R. G., Edgett, S. J., \& Kleinschmidt, E. J. (2000). New problems, new solutions: making portfolio management more effective. Research-Technology Management, 43(2), 18-33.

Archer, N., Ghasemzadeh, F., (1999b). Project portfolio selection techniques: a review and a suggested integrated approach. In: Dye, L.D., Pennypacker, J.S. (Eds.), Project Portfolio Management. Selecting and Prioritizing Projects for Competitive Advantage. Center for Business Practices, USA, pp. 207-238.

Artto, K., Dietrich, P., (2004). Strategic business management through multiple projects. In: Morris, P.W.G., Pinto, J.K. (Eds.), TheWiley Guide to Managing Projects. John Wiley \& Sons, New York, NY, pp. 1-33.

Artto, K.A., Dietrich, P.H., Nurminen, M.I., (2004). Strategy implementation by projects. In: Slevin, D.P., Cleland, D.I., Pinto, J.K. (Eds.), Innovations: Project Management Research. Project Management Institute, Newtown Square (PA), pp. 103-122.

Zika-Viktorsson, A., Sundström, P., Engwall, M., (2006). Project overload: an exploratory study of work and management in multi-project settings. Int. J. Proj. Manag. 24, 385-394.

Elonen, S., Artto, K., (2003). Problems in managing internal development projects in multi-project environments. International Journal of Project Management 21 (6), 395-402.

Martin Voss (2012). Impact of customer integration on project portfolio management and its successDeveloping a conceptual framework. International Journal of Project Management 30 (2012) 567-581.

Floricel, S., Ibanescu, M., (2008). Using R\&D portfolio management to deal with dynamic risk. R\&D Management 38 (5), 452-467.

Bessant, J., B. Von Stamm, K. M. Moeslein and A.O K. Neyer (2011). "Backing outsiders: selection strategies for discontinuous innovation."R\&D Management. 40(4): 3450356.

Stilling Blichfeldt, B., Eskerod, P., (2008). Project Portfolio Management there's more in it than what management enacts. International Journal of Project Management 26, 357-365.

Engwall, M., Jerbrant, A., (2003). The resource allocation syndrome: the prime challenge of multiproject management? International Journal of Project Management 21 (6), 403-409.

Salisu Gidado Dalibi, Hadiza Balarabe and Jamilu Bala MaiAuduga (2016): Green Buildings: A Concept aligning the interests of Stakeholders (Developers / Clients and End-users) in Estate Development Projects in Abuja - F.C.T (Federal Capital Territory), Nigeria. SBE16 Hamburg: Strategies - Stakeholders - Success factors. International Conference on Sustainable Built Environment in Hamburg, Germany. 7-11th March, 2016.

Project Management Institute-PMI, (2008a). A Guide to the Project Management Body of Knowledge (PMBOK® Guide) 4th Edition. published by PMI, Newton Square, P.A.

Project Management Institute, 2008b. The Standard for Portfolio Management, Second Edition. published by PMI, Newton Square, P.A.

Englund, R.L., Graham, R.J., (1999). From experience: linking projects to strategy.J. Prod. Innov. Manag. 16 (1), 52-64.

Martinsuo, M., Lehtonen, P., (2009). Project autonomy in complex service development networks. Int. J. Manag. Proj. Bus. 2 (2), 261-281.

Ahlemann, F., Teuteberg, F., Vogelsang, K., (2009). Project management standards - diffusion and application in Germany and Switzerland. International Journal of Project Management 27 (3), 292-303.

Garcia, S., (2005). How standards enable adoption of project management practice. IEEE Software 22, 2229.

Homburg, C., Workman, J.P., Jensen, O., (2002). A configurational perspective on key account management. Journal of Marketing 66 (2), 38-60.

Ernst, H., Hoyer,W., Krafft, M., Krieger, K., (2011). Customer relationship management and company performance - the mediating role of new product performance. Journal of the Academy of Marketing Science 39 (2), 290-306. 
Frow, P. \& Payne, A. J Bus Market Manage (2009). Customer Relationship Management: A Strategic Perspective. Journal of business market management February 2009, Volume 3, Issue 1, pp 7-27. 3: 7. https://doi.org/10.1007/s12087-008-0035-8.

Boulding,W., Staelin, R., Ehret,M., Johnston,W.J., (2005). A customer relationship roadmap: what is known, potential pitfalls, and where to go. Journal of Marketing 69 (4), 155-166.

Homburg, C., Droll, M., Totzek, D., (2008). Customer prioritization: does it pay off, and how should it be implemented? Journal of Marketing 72 (5), 110-130.

Homburg, C., Steiner, V.V., Totzek, D., (2009). Managing dynamics in customer portfolio. Journal of Marketing 73 (5), 70-89.

Terho, H., (2009). A measure for companies' customer portfolio management. Journal of Business-toBusiness Marketing 16 (4), 374-411.

Tikkanen, H., Kujala, J., Artto, K., (2007). The marketing strategy of a project based firm: the four portfolios framework. Industrial Marketing Management 36 (2), 194-205.

Cooper, R., Edgett, S., Kleinschmidt, E., (1997a). Portfolio management in new product development: lessons from the leaders I. Research Technology Management 40 (5), 16-28.

Benko, C., McFarlan, F.W., (2003). Connecting the Dots. Aligning Projects with Objectives in Unpredictable Times. Harvard Business School Press, USA.

Cooper, R.G., Edgett, S.J., Kleinschmidt, E.J., (2001). Portfolio Management for New Products, Second Edition. Perseus, Cambridge (MA).

M. Martinsuo, J. Poskela (2011). Use of evaluation criteria and innovation performance in the front end of innovation. J. Prod. Innov. Manag., 28, pp. 896914.

Müller, R., Martinsuo, M., Blomquist, T., 2008. Project portfolio control and portfolio management performance in different contexts. Project Management Journal 39 (3), 28-42.

Teller, J., Unger, B., Kock, A., Gemünden, H.G., (2012). Formalization of project portfolio management: the moderating role of project portfolio complexity. Int. J. Proj. Manag. 30 (5), 596-607.
Artto, K., Kujala, J., Dietrich, P., Martinsuo, M., (2008a). What is project strategy? International Journal of Project Management 26 (1), 4-12.

Artto, K., Martinsuo, M., Dietrich, P., Kujala, J., (2008b). Project strategy - strategy types and their contents in innovation projects. International Journal of Managing Projects in Business 1 (1), 49-70.

Loch, C., (2000). Tailoring product development to strategy: case of a European technology manufacturer. European Management Journal 18 (3), 246 -258.

Sushant n.d. (2018). Active Portfolio Management Strategy available at http://www.portfoliomanage ment.in/active-portfolio-management-strategy.html.

Johan Christian Hilsted. Active Portfolio Management and Portfolio Construction - Implementing an Investment Strategy Master Thesis, Fall 2012 Cand. Merc. Applied Economics and Finance Copenhagen Business School. Date of Submission: December 14th 2012.

URL:

https://www.investopedia.com/ask/answers/040315/w hat-difference-between-passive-and-active-portfoliomanagement.asp.

Raymond James and Associates (n.d.) Active vs. Passive Portfolio Management. Available at: https://www.raymondjames.com/weisswealthmanage ment/pdf/active_vs_passive.pdf.

Atrill, P. \& McLaney, E. (2011) Accounting and Finance for Non-Specialists. 7th Edition. Prentice Hall.

URL:https://www.investopedia.com/terms/c/conservative investing.asp.

URL: https://www.thebalance.com/conservative-mutualfund-portfolio-example-2466527.

URL:https://www.forbes.com/sites/duncanrolph/2013/10/ 30/5-rules-of-the-road-how-to-invest-a-conservativeportfolio-in-the-current-environment/\#6fc9f24244a5.

Robert V. Krejcie and Daryle W. Morgan (1970). Determining Sample Size for Research Activities. Educational and Psychological Measurement. 1970, 30, 607-610.

Mohsen Tavakol and Reg Dennick (2011). Making sense of Cronbach's alpha. International Journal of Medical Education. 2011; 2:53-55. ISSN: 2042-6372. DOI: 10.5116/ijme.4dfb.8dfd.

Cronbach, L. J. (1951). Coefficient alpha and the internal structure of tests. Psychometrika, 16,297-334. 


\section{Appendix - The Research Data Obtained}

Table: Project Portfolio Management (PPM) Strategies \& Ease of Application within Organizations

\begin{tabular}{|c|c|c|c|c|c|c|c|}
\hline $\mathbf{S} / \mathbf{N}$ & $\begin{array}{c}\text { Project Portfolio Management Strategies \& Ease of } \\
\text { Application }\end{array}$ & 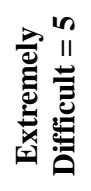 & 党 & 吕 & 艺 & 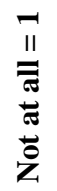 & 岕 \\
\hline 1 & Active Portfolio Management Strategy & 181 & 149 & 45 & 11 & 3 & 389 \\
\hline 2 & Passive Portfolio Management Strategy & 171 & 44 & 103 & 61 & 10 & 389 \\
\hline 3 & Patient Portfolio Management Strategy & 32 & 29 & 68 & 187 & 73 & 389 \\
\hline 4 & Aggressive Portfolio Management Strategy & 10 & 13 & 109 & 228 & 29 & 389 \\
\hline 5 & Conservative Portfolio Management Strategy & 19 & 27 & 56 & 219 & 68 & 389 \\
\hline
\end{tabular}

Table: Performances of Project Portfolio Management Strategies in Achieving Organizational Objectives in Portfolios

\begin{tabular}{|c|c|c|c|c|c|c|c|}
\hline $\mathbf{S} / \mathbf{N}$ & $\begin{array}{l}\text { Performances of Project Portfolio Management Strategies in } \\
\text { Achieving Organizational Objectives in Portfolios }\end{array}$ & 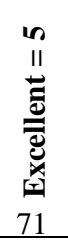 & 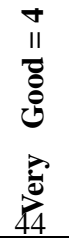 & $\begin{array}{l}\text { m } \\
\text { II } \\
\stackrel{0}{0} \\
0 \\
121\end{array}$ & 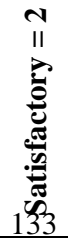 & 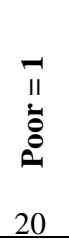 & 承 \\
\hline 1 & Active Portfolio Management Strategy & 57 & 147 & 85 & 88 & 12 & 389 \\
\hline 3 & Patient Portfolio Management Strategy & 88 & 189 & 68 & 28 & 16 & 389 \\
\hline 4 & Aggressive Portfolio Management Strategy & 15 & 11 & 19 & 79 & 265 & 389 \\
\hline 5 & Conservative Portfolio Management Strategy & 136 & 196 & 34 & 12 & 11 & 389 \\
\hline
\end{tabular}

